\title{
Humanistic Spirit Analysis of Traditional Opera in China and the West-Taking L'Orfeo and White-Haired Girl as Examples
}

\author{
Qin Yin
}

Art College, Xiamen University, Xiamen, 361005, China

Keywords: Opera, Humanistic spirit, Music

\begin{abstract}
As a form of music, opera is closely related to the expression of humanistic spirit and human emotion from its birth. This paper explores the profound effect of humanities spirit in the development and changes in Chinese and western operas from L'Orfeo and White-Haired Girl, which are the starting points of western operas and the Chinse opera respectively.
\end{abstract}

The "humanistic spirit" refers to the most influential ideological trend in the Western Renaissance. The basic connotation of the humanistic spirit is to pay attention to human nature, to respect the value of human beings, to pursue the all-round development of individual freedom and human nature. As an important part of the humanistic spirit, the spirit of music humanism embodies the functions of aesthetics, emotion and thought, and at the same time, people turn the aesthetic, emotional and ideological materialization into voice form, displaying their own "people-oriented" spirit. As a form of music, opera is closely related to the expression of humanistic spirit and expression of human emotion at the beginning of its birth [1].

\section{Humanistic Spirit is the Soul of Western Opera}

How to use music to express human nature and reflect the emotional state of human beings is the consistent goal of the composers who have the spirit of humanism in the Renaissance. In the sixteenth Century, the problem of music performance was the first time to be the center of the attention of theorists and composers. Even before the first batch of the Florentine classical opera script, humanist insists that, if the ancient Greece music has unparalleled strength and inspired imitation of human emotions, so today's music should be, and can recover lost territory [2].

From lyric to drama, it is the development track of Italy's Pastoral songs, and it also gives birth to dramatic opera art. As a prelude to "Orpheus" Monte Verdi has said, "music to the stage, designed to ignite the various, even" the cold soul "'. In 1600, the birth of the opera was the ultimate mission of the pastoral song - from lyric to the sublimation of the drama. As a result, the last songwriter was also the first opera composer. The most extreme result of the sixteenth Century belief in the emotional power of music, the birth of the opera, was the most extreme result. Western opera in the beginning deeply humanistic spirit and outstanding opera birthmark, steeped in the history of western music in each historical period and not by the humanistic spirit. From the original opera "Orpheus" to the classical period of "the marriage of Figaro", to twentieth Century. Every reform in the history of the development of opera on eighteenth Century, whether Gluck's reforms or at the end of nineteenth Century Wagner's music drama theory are for one purpose: to maximize the opera performance of human emotion, human reproduction of various emotional states: desire, desire, death and madness. Leaving the expression of human nature and human emotion, opera art can only be a rigid empty shell filled by commercial, stylized, superficial and dazzling techniques.

"Orpheus" is Monte Verdi's first opera, and the earliest stage works, February 24, 1607 and March 1st, the public premiere held in Mandu tile palace. A total of five opera scene, writing the story and the first Opera Club tamez, "Youlidiqian" Orfeo and similar: half the Greek demigod musician Orpheus's wife Youlidiqian unfortunately was bitten and poisoned, so looking for a wife to Hades orpheus. He has touched the cold by singing a marraenoloth, Pluto and Proserpina, was allowed to 
return to earth. Orpheus as an artist and met the requirements, but as ordinary people, but he can't control his emotions, strictly abide by the ban on pluto. In the face of the key situation, he couldn't help returning to his head and finally failed. However, we have seen the victory of great humanity behind the failure. In the face of the deep calling of lover, which flesh and spirit do not move for it? At this moment, the light of human nature is shining! Orpheus ultimately failed to save his wife, Apollo God Orpheus became a sign from the eternal light, so that he and Youlidiqian forever. In front to the heart in emotion, death also had to temporarily stop, to respect it! Is Orpheus moved back, later generations of musicians. Two hundred years later, the classical master Haydn to compose this an eternal myth, Gluck it as a repertoire of opera reform.

\section{Humanistic Spirit Hastened the Birth of the Expressive Techniques of Western Traditional Opera}

Monte Verdi's profound insight into human nature and his ability to portray characters with music are also embodied in the opera [3]. In this opera, a large number of pastoral, single song, singing and narration are used to harmonies various forms of instrumental music. The changes of expression of instrumental music scenes and atmosphere in the play in every prelude, interlude or after. The chanting and narration was the first creation of Mont Verdi and a great achievement in the history of the opera. Obviously, he is trying to use music to imitate the language according to his emotions. "Orpheus" arioso is based, and 35 years later, another of his masterpiece "coronation." a man, recitative still completely dominated, determines the structure. In his understanding of the ancient Greek tradition, the expressive force of the music not only means that the depiction of the atmosphere and the scene, he in the practice of a new classical ideal new music: emotional speech should imitate tone, should pursue the rhythm, mining connotation words touching. The result is the intense emotion, the cry from the heart, the concealed instinct of human nature in rhyming poetry, the new form of music that is concerned with speaking and singing, and the inventions of chanting tune.

In order to express the dramatic drama, show the great conflict in the character, he carefully excavated every kind of means to increase the tension. Read in the rhythm or prompted him to halt, or even guns such as beads, in the melody on his cadence. Sometimes, he overlaps the different chords in a radical way, but his basic harmony is not complicated. The discord between the singing voice and the harmonies under it complements the tension of the harmony. Sometimes, he even intentionally emphasizes the intense dissonance in the harmony, and does not solve it. Usually, even if he solves the disagreement with the chord, it is more intense and sharp. Or, he temporarily uses a sharp chord tone to introduce new tension. One of Mont Verdi's other means to show the storyline, to show the emotions of the characters is to use the slitting rhythm. The segmentation means the tension in the rhythm, just as the dissonance is the tension in the harmony. In tradition, the slitting and discordant sounds are often intentional together with the aim of emphasizing the coming termination.

This opera arias is excellent for countless, ubiquitous. Aria, as one of the main means of expression in opera, plays an important role in depicting the character of the play vividly. This way of expressing the human nature is undoubtedly consistent with the spirit of those humanists. Quartet plays an important role in Mozart's opera, it not only depicts different characters, but also serve as an important task to express drama conflict, especially in the final act, music constantly provide opportunities for more roles to join the Quartet and duet, forming five songs, even seven Duet (see "Figaro the wedding ceremony" the second act final, which will play a climax.

It can be seen that the humanistic spirit is the catalyst for opera production. In the history of opera, the invention of every musical method is inseparable from the basic theme of expressing human nature and human emotion. Also, whenever the development of opera into a stylized, commercial, superficial virtuoso bars, humanistic spirit, to be as a spiritual force, guide.

The composers have carried out a series of reform measures for the opera. Therefore, the humanistic spirit is the soul of the western opera. Without the surging of the humanistic spirit, there is no production and development of opera. 


\section{Humanistic Spirit is the Theme that Traditional Chinese Opera Expresses}

To mention Chinese opera, you can't ignore the important position of the "white haired woman". The white haired woman is the first mature Chinese opera, which marks the development of Chinese opera into a new stage. "White haired girl" began writing in 1945. It is based on a new folk legend spread in the Shanxi Chinar Hebei Jiefang District story, the play was torn through a despotic landlord peasant girl forced into "the tragic story the white haired girl", reveals the miserable life of farmers under feudal oppression, but also reflects the farmers under the leadership of the Communist Party turn bright reality liberation. It reveals the profound connotation of "the old society turns people into ghosts, and the new society turns ghosts into people." The selection of white haired women has laid a good foundation for the development of Chinese opera, namely, paying attention to the sufferings of the poor people in the lower class and appealed to the dignity and value of the weak. This concept is not available in Western operas, because in the more than 200 years of opera production in the west, opera is a kind of art entertainment for the nobility to enjoy and entertain. And, on the subject, myths and legends occupy the most part of the opera. It was not until the emergence of realism in nineteenth Century that the situation was slightly relieved. From this point of view, Chinese opera pays more attention to the concern of humanity and evil, beauty and ugliness than the Western operas, which is also the performance of Chinese profound humanistic spirit tradition in opera [4].

From the perspective of specific musical expression, the music of white haired girl is also very successful in depicting the character and the development of the plot. It develops and creates character based tones on the basis of folk tones. The composer according to the characters of character, choose suitable folk tones, as a basis for creating this character main tone, and then in accordance with the requirements of the development of the plot, to expand on this theme and main tone, tone or add supplementary description of the character of other side. Among them, the most successful is the protagonist of the play, the tone of the white haired girl who, the basic material collected from Hebei folk song "little cabbage", it slowly down, what the whining tone, provides the basic tone for the play you mouth with a degree of Copts moon "image of the lonely and helpless. This tune of innocence, you just play simple cute image is not suitable, so in the composer's "basic Chinese cabbage" written on the "north wind" ". It keeps the "little cabbage" down the melody and sound characteristics, but the expansion of the range, changing the rhythm and melody of figure, detail processing, so that the music is lively and fluent, brisk euphemism, as you draw just out of a vivid portrait". The main tone and appearance tone "cheerful north wind" in stark contrast to the two tones respectively as two important characterizations of personality development in baking you to become a main tone, throughout the play, to show the plot development, reproduction conflict, character changing role. In addition, the main tones of Yang Bai Lao in the white haired girl, as well as the tones of Huang Shiren, Mu Renzhi and Huang mu, were created and played on the basis of folk songs and traditional music tones.

\section{Humanistic Spirit Creates Music Images in Traditional Chinese Opera}

With the continuous change of the plot and character, the white haired woman makes the dramatic development of the main tone of the characters. The composers widely used the processing of the main tones of characters, such as planing and reciting, making the theme tone run through the development way, thus creating a complete music image. You still to the music image as an example: the shaping of her musical image has undergone the following four stages of development: the first stage, showing the image of young girls and her daughter naivete and his father by the feeling of the father, the main aria is "north wind", "I hope Daddy" and "tie a red ribbon". Is the pure lyric music image. The second stage, with the development of the story, the character of Xi Er suffered from tragedy after sharp change, anger, resentment, shame all kinds of complex emotions intertwined, is the main Aria "yesterday night", "home" and "into his sword", with the "north wind" of the theme tune for various changes among them, Xi Er, who accused the "sword" I, with more dramatic 
techniques in opera plate cavity, with Xi Er still cry father tones of development, and the use of the opera in the voice crying crying in the cavity in another theme of "Allegro close to Xi Er, they're going to kill me." tone, indicated the trend of development of the musical image of the next. The third stage performance in Huang Shiren's awakening you step by step under persecution, lost by a bear girl, became fled into the mountains, and vowed revenge of the "white haired lady", this is the climax of the play, to the image of the white haired girl from you shape has been completed, the character and image are from a qualitative leap. The plot and corresponding character development is clearly reflected in the music: music is mainly based on high pitched tone "revenge and they're going to kill me" on, at the same time, but also the integration of the "north wind" and the main tone you cry father tone, so as to keep the image of music the internal logic of coherence, the composer at this stage of development of Xi'er revenge made adequate rendering of the most incisive play, make music in this form the climax of the play. In this music, the various musical elements of the previous stages of development and the tone of each subject are integrated. In her singing, singing with the other characters and the masses of the background story of chorus. In this piece of music, such as some prototype reproduction, "I hope Daddy" tone, reminiscent of the girl who humiliated before naivete image; some do, with more ups and downs of the form, and the hearts of the implacable resentment to talk to you. You accused of singing, still uses the technique of cavity plate, from "I" to "the sun, which is similar to the injustice Shen" opera "scattered fast (shaking plate, 26) - slow (the original plate, Adagio) - Fast - full plate scattered", showing you from unspeakable pain, to cry cry, from the back to running and filled with a thousand regrets, draining the rage, finally to have mixed feelings. This depiction, distinct arias, with accompaniment, choral and instrumental accompaniment Huicheng River, the climax of music. In addition to your image, other characters, such as Yang Bailao, also very successful.

In addition, in order to fully show the dramatic plot, a more detailed portrait of the character, the composer also used a typical Western drama, singing ensemble and chorus, as a "white haired girl" the Opera plays an important role in shaping the success of. It can be seen that the opera "white haired girl" shows the deep humanistic spirit of China from the theme to the means of musical expression, which is the source of the eternal charm of the opera. After the white haired girl, a large number of excellent Chinese operas were produced, such as Liu Hulan and wilderness. These operas were more or less influenced by the white haired girl.

There is no doubt that the humanistic spirit is an important birth force produced by the opera and the soul of the traditional Western opera. At the same time, it is also the theme of Chinese traditional opera. Without the ultimate concern of the humanistic spirit, opera art can only be empty and superficial, commercialized and stylized.

\section{References}

[1] Chen Lihong. The Influence Of the Humanistic Spirit on Bach’s Music [J]. Journal of Jiangxi Science \& Technology Normal University, 2014(5): 114-118.

[2] Xiong Xiaohui. Humanistic Spirit in Miao Badai Ritual Music [J]. Tribune of Education Culture, 2015(4): 77-83.

[3] Li Wei. A Discussion on How to Cultivate the Humanistic Spirit in Teaching National Music [J]. Explorations in Music, 2010(3): 105-107.

[4] Luo Bing. Humanistic spirit of the ancient opera identity-from the perspective of constructing the opera banter entertainment character [J]. Journal of Xinyu University, 2013, 18(6): 12-14. 